\title{
Tissue Lipoprotein Lipase in Normal Individuals and in Individuals with Exogenous Hypertriglyceridemia and the Relationship of This Enzyme to Assimilation of Fat*
}

\author{
William R. Harlan, Jr., $\nmid$ Preston S. Winesett, $\$$ and \\ Albert J. Wasserman \\ (From the Department of Medicine, Medical College of Virginia, Richmond, Va.)
}

\begin{abstract}
Summary. Lipoprotein lipase activity (LLA) was measured in the adipose tissue of six healthy subjects and five members of a family in whom the trait for familial exogenous hypertriglyceridemia was segregating. The lipase activity measured was characteristic of lipoprotein lipase: increased by feeding, dependent on the presence of serum, and inhibited by sodium chloride and protamine sulfate. When compared with lipase activity in healthy individuals, LLA was grossly deficient in two siblings with postabsorptive chylomicronemia and was intermediate in both parents and one sibling, who had normal postabsorptive triglycerides. These findings are compatible with autosomal recessive inheritance. The hormone-sensitive lipolytic enzyme responsible for mobilization of free fatty acids from adipose storage was normal in the hyperlipemic subjects.

After a 104-g fat meal, the serum triglyceride increased more in subjects heterozygotic for LLA deficiency than in the healthy subjects, and there was a relatively greater increase in chylomicrons and very low density lipoproteins in the affected individuals. These observations demonstrate the physiologic importance of lipoprotein lipase in removal of these lipoprotein groups and further clarify the differences between endogenous and exogenous hypertriglyceridemia.
\end{abstract}

\section{Introduction}

Familial hypertriglyceridemia may be classified as "fat-induced" and "carbohydrate-induced" hyperlipemia depending on the response of plasma triglyceride to isocaloric substitutions of dietary fat and carbohydrate $(1,2)$. In the fat-induced (exogenous) form, affected individuals have post-

* Submitted for publication June 20,1966; accepted October 27, 1966.

Supported by U. S. Public Health Service grants HO 7364 and FR 0065 from the General Clinical Research Center.

A partial report of this work was read before the Southern Society for Clinical Investigation, January 28, 1966.

$\dagger$ Address requests for reprints to Dr. William R. Harlan, Medical College of Virginia, Richmond 19, Va.

$\ddagger$ Recipient of a summer fellowship from the Richmond Area Heart Association. absorptive hypertriglyceridemia and chylomicronemia when the diet contains normal levels of dietary fat, but plasma lipids decrease strikingly when these individuals receive diets restricted in fat ( 0 to $5 \mathrm{~g}$ per day). This inability to handle normal quantities of dietary triglyceride has been attributed to a deficiency of lipoprotein lipase, an enzyme facilitating hydrolysis and clearance of triglyceride from plasma (2). This enzyme is present in many tissues, principally heart and adipose tissue, and it is present also in plasma after heparin administration, which presumably causes release from tissue (3-5). Enzymatic activity in adipose tissue is diminished by fasting but increased by refeeding, characteristics compatible with a physiologic role in assimilation of dietary lipid. 
Postheparin plasma from individuals with exogenous hypertriglyceridemia has less lipase activity $(2,5,6)$. However, lipoprotein lipase is principally, if not entirely, a tissue enzyme, and plasma assays represent an indirect measure of tissue enzymatic activity. The lack of sensitivity and specificity of plasma assay is demonstrated by the inability in some studies (6) to detect all affected individuals, particularly presumed heterozygotes, and by the incomplete inhibition of lipase activity by sodium chloride, which inhibits lipoprotein lipase (3). To circumvent these difficulties and to define the role of this enzyme in assimilation of triglyceride, we assayed lipoprotein lipase in the subcutaneous adipose tissue of normal individuals and members of a family in which the trait for exogenous hypertriglyceridemia was segregating. The levels of enzymatic activity, demonstrated to be lipoprotein lipase, were correlated with glyceride removal after a high fat meal. Deficiencies of tissue lipoprotein lipase were found in the affected family and were associated with altered clearing of dietary fat. The lipolytic system that mobilizes fatty acids from adipose depots through a different biochemical mechanism was also assessed in hyperlipemic individuals and found to be normal.

\section{Methods}

Subjects. Members of a single affected kindred and healthy individuals were studied. The relationships of members of the kindred, who were Negro, are outlined in Table I. The parents were first cousins and both were healthy with no stigmata of hyperlipemia. The propositus (I.B.) and her sister (P.B.) had recurrent episodes of abdominal pain which, in the propositus, were due to recurrent pancreatitis and led to her death (7). These siblings had eruptive xanthomata and moderate hepatic and splenic enlargement. Their brother (Mo.B.) had only hepatomegaly as a manifestation of hyperlipemia. Other members of the family were healthy, and glucose tolerance tests were normal in all of the kindred. Plasma and tissue lipase activity were not measured in the propositus, but were measured in both parents (J.B. and Ma.B.) and in three siblings (G.B., Mo.B., and P.B.) two of whom were known to have hyperlipemia (8). Male and female medical personnel of comparable age and weight and without known disease served as normal subjects. One of these latter subjects (P.W.) was found during these studies to have elevated plasma triglyceride and was considered separately.

Procedures. All subjects were hospitalized on the Clinical Research Center the day of study, and members of the hyperlipemic family were hospitalized for 5 days before study to provide dietary regulation since the preceding diet may affect lipoprotein lipase activity (5). For 5 days or more before study, all subjects consumed a diet containing at least $40 \%$ of the calories as fat. On the day of study, each subject received a liquid test meal composed of cream, sugar, and flavoring and con-

TABLE I

Postabsorptive serum lipids in the affected family and in healthy subjects

\begin{tabular}{|c|c|c|c|c|c|c|c|c|}
\hline $\begin{array}{l}\text { Subject and relation } \\
\text { to propositus }\end{array}$ & Age & Height & Weight & $\begin{array}{l}\text { Tri- } \\
\text { glyceride }\end{array}$ & Cholesterol & Phospholipid & Chylomicrons & $\begin{array}{c}\text { Plasma } \\
\text { lipoprotein lipase }\end{array}$ \\
\hline J.B. & years & inches & pounds & $m g / 100 m l$ & $m g / 100 m l$ & $m g / 100 m l$ & $\%$ total lipid & $\mu E q F F A / m l / \min$ \\
\hline Father & 44 & 67 & 145 & 117 & 263 & 195 & 7 & $0.20,0.16,0.22$ \\
\hline $\begin{array}{l}\text { Ma.B. } \\
\text { Mother }\end{array}$ & 42 & 68 & 160 & 102 & 267 & 193 & 7 & 0.09 \\
\hline $\begin{array}{l}\text { I.B.* } \\
\text { Propositus }\end{array}$ & 24 & 65 & 114 & 3,540 & 495 & 425 & 79 & \\
\hline $\begin{array}{l}\text { P.B. } \\
\text { Sister }\end{array}$ & 16 & 66 & 106 & 2,792 & 279 & 278 & 48 & 0.12 \\
\hline $\begin{array}{l}\text { Mo.B. } \\
\text { Brother }\end{array}$ & 19 & 67 & 110 & 2,630 & 260 & 219 & 52 & 0.08 \\
\hline $\begin{array}{l}\text { G.B. } \\
\text { Brother }\end{array}$ & 24 & 69 & 138 & 121 & 255 & 117 & 8 & $0.15,0.20$ \\
\hline $\begin{array}{l}\text { C.B. } \\
\text { Sister }\end{array}$ & 21 & 65 & 90 & 53 & 198 & 138 & 7 & 0.25 \\
\hline Healthy subjects $†$ (5) & $18-38$ & $64-72$ & $123-184$ & $\begin{array}{c}81 \\
\text { (range } 54-102)\end{array}$ & $\begin{array}{c}225 \\
\text { (range 188-282) }\end{array}$ & $\begin{array}{c}160 \\
\text { (range 117-198) }\end{array}$ & $\begin{array}{c}3 \\
\text { (range } 0-7)\end{array}$ & $\begin{array}{c}0.34 \\
\text { (range } 0.20-0.46)\end{array}$ \\
\hline P.W. & 27 & 70 & 170 & 226 & 287 & 267 & 5 & 0.37 \\
\hline
\end{tabular}

* Values from previous study (8).

$\dagger$ Exclusive of P.W. 
taining $104 \mathrm{~g}$ fat, $34 \mathrm{~g}$ carbohydrate, and $10 \mathrm{~g}$ of protein. The subjects were limited to light activity thereafter and received a meal containing 200 calories and less than $2 \mathrm{~g}$ of fat 6 hours later.

Venous blood samples were obtained after an overnight fast and at $3,5,8$, and 12 hours after the test meal. Five hours after the fat meal, an area over one hip was anesthetized with xylocaine, particular care being taken to avoid infiltration of the adipose tissue. Two to $4 \mathrm{~g}$ of adipose tissue was removed through a small incision. The tissue was rinsed in cold $0.9 \%$ saline, blotted dry, and weighed.

Analytical methods. Lipoprotein lipase activity in adipose tissue was measured with the method outlined by Robinson (9). In this procedure, defatted tissue powder is prepared by extracting adipose tissue with acetone and ether; this powder is incubated with a lipoprotein substrate and necessary cofactors, and the release of free fatty acids (FFA) determined. Duplicate incubations were performed on each sample of tissue, and each incubation contained the following: $2.4 \mathrm{ml}$ of $20 \%$ bovine albumin (Fraction V Armour), $1.0 \mathrm{ml} 1.35 \mathrm{M}$ tris (hydroxymethyl)aminomethane buffer at $\mathrm{pH} 8.1,4 \mathrm{U}$ of heparin, $1.8 \mathrm{ml}$ of serum-Ediol mixture $(15 \mathrm{mg}$ of triglyceride per $\mathrm{ml}$ ), and $15 \mathrm{mg}$ of acetone/ether powder, which was homogenized in $0.025 \mathrm{M}$ ammonium hydroxide adjusted to $\mathrm{pH} 8.5$. The volume of each incubation was adjusted to $9 \mathrm{ml}$ by addition of distilled water. In most instances, the inhibitory effect of $\mathrm{NaCl}$ was determined in a third incubation that contained $0.4 \mathrm{M} \mathrm{NaCl}$ in place of water. In two instances, incubations were further altered by addition of protamine sulfate $(5 \mathrm{mg})$ or by replacement of serum-Ediol mixture by Ediol. After addition of the acetone/ether powder, the tubes were incubated with shaking at $37^{\circ} \mathrm{C}$. Duplicate samples of $1 \mathrm{ml}$ were removed from each tube at 5 minutes and $65 \mathrm{~min}$ utes after starting the incubation. The free fatty acids (FFA) were extracted in these samples and titrated (10). Lipase activity was expressed as microequivalents of FFA released per gram of adipose tissue per hour. In preliminary studies, the release of FFA was found to be linear during a period of 90 minutes. Our preliminary studies using this assay in adipose tissues of rabbits and rats yielded activities of 35 to $42 \mu \mathrm{Eq}$ FFA per $\mathrm{g}$ per hour, which are comparable to activities reported by others $(9,11)$.

Samples of serum were analyzed for triglyceride (12), cholesterol (13), and lipid phosphorus (14). The lipid phosphorus value was multiplied by 25 to yield phospholipid concentration. Postheparin plasma lipoprotein lipase activity was assayed by the method of Fredrickson, Ono, and Davis (5). The method of Lees and Hatch (15) was used for electrophoresis of serum lipoproteins. After electrophoresis, the strips were stained with oil red $O(15)$, and the intensity of staining of each fraction was quantified by scanning with the Beckman Analytrol. Because the prebeta fraction is poorly defined when levels of triglyceride are normal or near normal, serum lipoproteins were analyzed ultracentrifugally at the Institute of Medical Physics, Belmont,
Calif., by the method of De Lalla and Gofman (16). Only samples from the affected family before and 5 hours after the fat meal were analyzed in this manner.

Other studies. The response of plasma lipids to alteration of dietary fat was determined in the hyperglyceridemic subjects during another hospitalization. Dietary fat was alternated between $80 \mathrm{~g}$ per day and $5 \mathrm{~g}$ per day for 7 days while isocaloric balance was maintained primarily by substitution of carbohydrate.

The hormone-sensitive lipolytic system that mobilizes fatty acids from adipose tissue was assessed by measuring the response to epinephrine infusion (17). After an overnight fast and in the basal state, the hyperglyceridemic subjects received intravenous infusions of epinephrine, $2 \mu \mathrm{g}$ per minute for 15 minutes. Venous blood samples wer obtained and analyzed for FFA. The response of FFA to epinephrine in these subjects was compared with that of seven normal subjects.

\section{Results}

Serum lipids. Postabsorptive serum triglyceride levels were high in the propositus and two siblings (Mo.B. and P.B.) ; this triglyceride was present predominantly as chylomicrons (Table I). Serum triglyceride levels were normal in other members of this family, and none had postabsorptive chylomicronemia. Postheparin lipase was low in the mother (Ma.B.) and in the two siblings with hypertriglyceridemia, but results in the father (J.B.) and one sibling (G. B.) were variable and inconclusive. Repeated determinations did not clarify the status of these subjects, and the variability was apparently not related to diet. The serum cholesterol levels of J.B., Ma.B., and G.B. were higher than other members of this kindred having normal plasma lipoprotein lipase activity (18). The $S_{f} 0$ to 12 lipoproteins were also high in these subjects (J.B., $521 \mathrm{mg}$ per $100 \mathrm{ml}$; Ma.B., $445 \mathrm{mg}$ per $100 \mathrm{ml}$; G.B., $485 \mathrm{mg}$ per $100 \mathrm{ml}$ ), but the postabsorptive levels of other lipoproteins were normal.

After the hyperlipemic subjects had been on a 5-g fat diet for 4 days, the plasma triglyceride decreased from values shown in Table I to $745 \mathrm{mg}$ per $100 \mathrm{ml}$ (P.B.) and $620 \mathrm{mg}$ per $100 \mathrm{ml}$ (Mo.B.). This decrease was associated with clearing of turbidity, almost complete disappearance of chylomicrons $(<10 \%)$, and development of a prebeta band. Similar responses to low fat diets have been reported by Lees and Fredrickson (19) in members of other kindred having exogenous hypertriglyceridemia.

Serum lipids and postheparin lipase activity 
TABLE II

\begin{tabular}{|c|c|c|c|c|}
\hline \multirow[b]{2}{*}{ Subject } & \multicolumn{4}{|c|}{ Lipoprotein lipase activity } \\
\hline & No. 1 & No. 2 & $+\mathrm{NaCl}$ & $\begin{array}{l}\text { Mean of no. } 1 \\
\text { and no. } 2\end{array}$ \\
\hline Healthy & \multicolumn{4}{|c|}{$\mu E q F F A / g / h o u r$} \\
\hline $\begin{array}{l}\text { S.I. } \\
\text { G.B. } \\
\text { J.R. } \\
\text { K.M. } \\
\text { W.H. } \\
\text { P.W.* }\end{array}$ & $\begin{array}{l}21.3 \\
19.1 \\
17.9 \\
15.3 \\
23.9 \\
18.3\end{array}$ & $\begin{array}{l}19.2 \\
18.0 \\
16.6 \\
15.8 \\
11.9 \\
16.4\end{array}$ & $\begin{array}{l}0.2 \\
0.9 \\
7.8 \\
3.4 \\
2.6 \\
0.7\end{array}$ & $\begin{array}{l}20.3 \\
18.5 \\
17.2 \\
15.5 \\
17.9 \\
17.3\end{array}$ \\
\hline \multicolumn{5}{|c|}{ Affected family } \\
\hline $\begin{array}{l}\text { J.B. } \\
\text { Ma.B. } \\
\text { P.B. } \\
\text { Mo.B. } \\
\text { G.B. }\end{array}$ & $\begin{array}{r}10.9 \\
8.8 \\
2.9 \\
3.8 \\
8.7\end{array}$ & $\begin{array}{l}9.0 \\
8.5 \\
2.9 \\
3.6 \\
7.5\end{array}$ & $\begin{array}{l}0.8 \\
1.6 \\
1.8\end{array}$ & $\begin{array}{l}9.6 \\
8.6 \\
2.9 \\
3.7 \\
8.1\end{array}$ \\
\hline
\end{tabular}

* Subject with elevated postabsorptive serum triglyceride.

were normal in all healthy subjects except P.W. This subject had elevated plasma triglyceride, a small prebeta band, and normal plasma lipase activity. An abnormal glucose tolerance test was found later, and he was assumed to have endogenous hypertriglyceridemia (20).

Lipoprotein lipase in adipose tissue. Lipase activity in subcutaneous adipose tissue of normal subjects in these studies was comparable to activities reported by others $(21,22)$ in human adipose tissue obtained after feeding, but less than that reported in adipose tissue of animals (23) (Table II). Duplicate determinations on the same tissue agreed substantially, and the activities measured in all normal individuals were similar (mean $17.8 \mu \mathrm{Eq}$ FFA released per $\mathrm{g}$ per hour). Although not very different, tissue lipase activity was slightly greater in the lean subjects (S.I. and G. B.) than the most obese subject (K.M.). Tissue lipase activity was normal in P.W., the subject with endogenous hyperglyceridemia.

Several lines of evidence confirmed that this lipase activity was lipoprotein lipase. Addition of $\mathrm{NaCl}$ (Table II) caused marked inhibition of lipase activity (range 55 to $99 \%$ ) ; the incubation exhibiting the least inhibition had less than half the amount of sodium chloride added as did the other incubations. Addition of protamine sulfate or replacement of the serum-Ediol substrate by
Ediol in two incubations each yielded activity that was less than $5 \%$ of that of the complete system. In addition, preliminary studies of adipose tissue from four fasted patients undergoing surgery yielded lower lipase activity ( $8.2 \mu \mathrm{Eq}$ FFA per $\mathrm{g}$ per hour, range 6.2 to 9.5 ) than tissue from subjects fed before biopsy. The increased activity in fed subjects, the inhibition by $\mathrm{NaCl}$ and protamine sulfate, and the requirement for serum are characteristic of lipoprotein lipase.

Tissue LLA in the hypertriglyceridemic subjects (Mo.B. and P.B.) was approximately $20 \%$ of that in the healthy subjects, and addition of $\mathrm{NaCl}$ produced relatively less inhibition, suggesting that a proportion of the lipolytic activity measured might not have been lipoprotein lipase. Both parents (J.B. and Ma.B.) and a sibling (G.B.) had tissue LLA that was intermediate (mean 8.8 $\mu \mathrm{Eq}$ FFA per g per hour) between normal levels and levels in the hyperlipemic individuals. No tissue studies were performed in the propositus and a healthy sibling, C.B. When individuals with grossly deficient tissue LLA were classified as homozygotic for LLA deficiency and those with intermediate levels as heterozygotic for this trait, the pattern of inheritance was compatible with that of a recessive trait (Figure 1 ).

Serum lipid changes with a high fat meal. The relationship between tissue LLA and clearing of alimentary lipemia was examined in the healthy

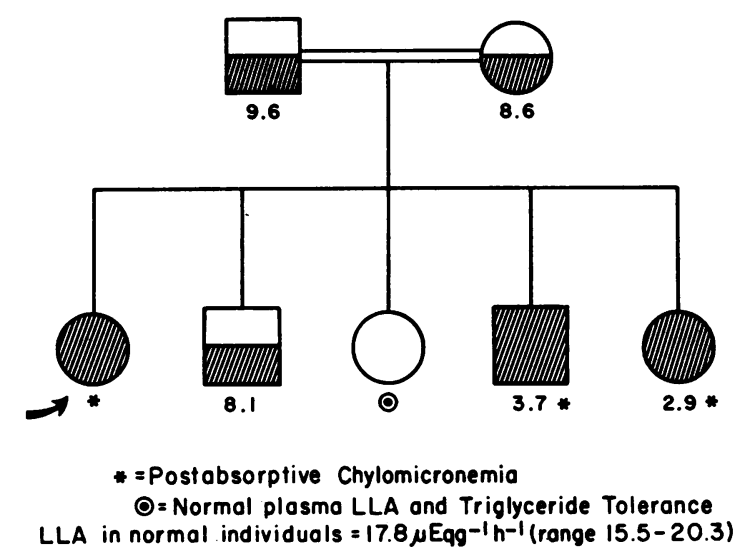

Fig. 1. Lipoprotein Lipase aCtivity (LLA) in the AFFECTED FAMILY. Fully shaded symbols indicate individuals homozygotic for lipoprotein lipase deficiency and half-shaded symbols individuals heterozygotic for deficiency. All studies in C.B. were normal, although she would not permit adipose tissue biopsy. These observations are compatible with a recessive inheritance. 


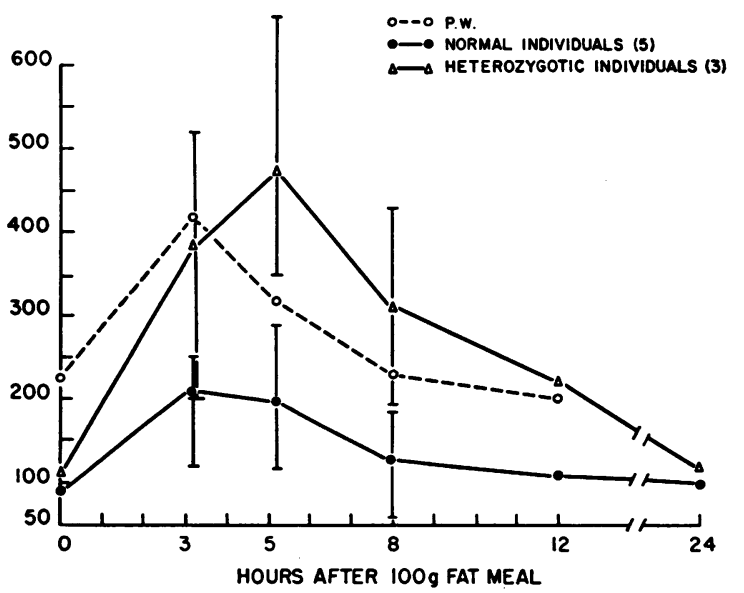

Fig. 2. SERUM TRIGLYCERIDE Changes AFter a 104-G FAT MEAL. The range of values for the normal and heterozygotic groups is shown by brackets. Triglyceride levels at 5 hours discriminate best between normal subjects and those heterozygotic for LLA deficiency. Subject P.W., who had endogenous hypertriglyceridemia, is shown separately.

subjects and the affected family. The changes in plasma triglyceride and relative amounts of serum lipoproteins after a $104-\mathrm{g}$ fat meal are presented in Figure 2 and Table III. Since the number of observations is small, the range of values is given in brackets. Healthy individuals with normal postabsorptive triglyceride levels $(<150 \mathrm{mg}$ per $100 \mathrm{ml}$ ) had a mean increase of $116 \mathrm{mg}$ per $100 \mathrm{ml}$ that was maximal at 3 hours; the serum triglyceride returned to normal at 12 hours. At
3 to 5 hours, there was an increase in chylomicrons and in the "trail" (very low density) fraction. This was followed by an increase in the proportion of prebeta lipoproteins at 5 and 8 hours. The sixth healthy subject, P.W., who had normal tissue LLA but elevated triglyceride, experienced a greater increase in plasma triglyceride at 3 hours (Figure 2) and a relatively greater increase in chylomicrons $(26 \%)$ at 3 hours and in prebeta lipoprotein $(23 \%)$ at 5 hours than the other healthy subjects.

The three heterozygotic subjects, who had intermediate levels of LLA and normal postabsorptive triglyceride levels, had significantly different responses after the fat meal. The plasma triglyceride was significantly higher at 5 and 8 hours than in the healthy subjects (Figure 2). A greater proportion of lipid was present in chylomicrons, trail, and prebeta lipoproteins in the heterozygotic individuals. The differences in chylomicrons and trail were statistically significant at 5 hours $(p<$ .01 ) and those in the prebeta fraction at 3 hours $(p<.05)$. More quantitative determination of prebeta lipoproteins by ultracentrifugation agreed with the electrophoretic estimates. The mean increases in lipoproteins for the three heterozygotes at 5 hours were as follows: $S_{\mathrm{f}} 20$ to $100,70 \mathrm{mg}$ per $100 \mathrm{ml}$ (range 67 to $85 \mathrm{mg}$ per $100 \mathrm{ml}$ ), and $\mathrm{S}_{\mathrm{f}} 100$ to $400,91 \mathrm{mg}$ per $100 \mathrm{ml}$ (range 49 to 134 $\mathrm{mg}$ per $100 \mathrm{ml}$ ). Although comparable data are not available on normal individuals after a 104-g

TABLE III

Serum triglyceride and lipoproteins after a 100-g fat meal in normal individuals and in individuals with deficient tissue lipoprotein lipase activity (LLA)

\begin{tabular}{|c|c|c|c|c|c|c|}
\hline \multirow{2}{*}{$\begin{array}{l}\text { Hours after } \\
\text { fat meal }\end{array}$} & \multirow[b]{2}{*}{ Serum triglyceride } & \multicolumn{5}{|c|}{ Lipoprotein fractions (electrophoresis) } \\
\hline & & Chylomicrons & "Trail" & Beta & Prebeta & Alpha \\
\hline \multicolumn{2}{|c|}{ Healthy subjects $(\mathrm{n}=5)^{*}$} & \multicolumn{5}{|c|}{$\%$ total } \\
\hline $\begin{array}{c}\text { Fasting } \\
3 \\
5 \\
8\end{array}$ & $\begin{array}{l}81(54-102) \dagger \\
205(121-257) \\
196(109-291) \S \\
132(51-186) \S\end{array}$ & $\begin{array}{l}3(0-7) \\
18(10-22) \\
15(9-19) \S \\
12(7-15)\end{array}$ & 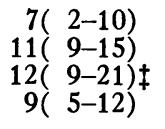 & $\begin{array}{l}50(44-61) \\
40(30-53) \\
36(26-44) \\
40(32-45)\end{array}$ & $\begin{array}{c}9(2-20) \\
8(4-19) \ddagger \\
12(5-26) \\
13(7-24)\end{array}$ & $\begin{array}{l}30(28-35) \\
24(20-31) \\
24(19-31) \\
27(23-31)\end{array}$ \\
\hline \multicolumn{7}{|c|}{ Heterozygotic for LLA deficiency $(n=3)$} \\
\hline $\begin{array}{c}\text { Fasting } \\
3 \\
5 \\
8\end{array}$ & $\begin{array}{l}113(102-121) \\
384(187-529) \\
476(384-668) \S \\
371(191-430) \S\end{array}$ & $\begin{array}{l}5(2-8) \\
29(19-36) \\
27(25-31) \S \\
20(14-29)\end{array}$ & $\begin{array}{c}7(7-8) \\
9(6-13) \\
22(21-23) \ddagger \\
13(7-18)\end{array}$ & $\begin{array}{l}53(46-64) \\
28(23-36) \\
22(21-23) \\
33(28-38)\end{array}$ & $\begin{array}{l}17(11-20) \\
19(14-25) \ddagger \\
23(23-25) \\
17(14-22)\end{array}$ & $\begin{array}{l}18(14-22) \\
13(10-20) \\
13(10-19) \\
15(10-19)\end{array}$ \\
\hline
\end{tabular}

* Does not include P.W.

$\dagger$ Mean and range.

$\ddagger \mathrm{p}<.05$ between analogous fractions.

$\S \mathrm{p}<.01$ between analogous fractions. 
fat meal, previous studies of 24 normal men using a meal containing $120 \mathrm{~g}$ of fat gave the following results: $\mathrm{S}_{\mathrm{f}} 20$ to $100,35.5 \pm 21.5$ (SD) $\mathrm{mg}$ per 100 , and $S_{\mathrm{f}} 100$ to $400,36.0 \pm 33.8 \mathrm{mg}$ per 100 (24). The meals are roughly equivalent on a per weight basis ( $1.5 \mathrm{~g}$ fat per $\mathrm{kg}$ ) in the two groups since the latter group was heavier. Nevertheless, the increase in both lipoprotein fractions was significantly greater $(\mathrm{p}<0.01)$ in the heterozygotic individuals. Thus, individuals heterozygotic for deficiency of LLA had a greater increase in plasma triglyceride, chylomicrons, and very low density lipoproteins after a high fat meal.

The response of one subject homozygotic for LLA deficiency (P.B.) to a 100 -g fat meal was studied after she had been on a $5-\mathrm{g}$ fat diet to reduce the pool of circulating triglyceride. The following values were obtained: fasting, $632 \mathrm{mg}$ per $100 \mathrm{ml} ; 3$ hours after the meal, $1,303 \mathrm{mg}$ per 100 $\mathrm{ml}$; 5 hours, $1,699 \mathrm{mg}$ per $100 \mathrm{ml} ; 8$ hours, 2,228 $\mathrm{mg}$ per $100 \mathrm{ml} ; 12$ hours, $2,422 \mathrm{mg}$ per $100 \mathrm{ml}$; and 24 hours, $2,264 \mathrm{mg}$ per $100 \mathrm{ml}$. This response is similar to that reported by others $(1,2)$ in patients with fat-induced hyperlipemia. On electrophoresis, the increase in lipid was confined to the chylomicron and trail fractions. The results in the unaffected sibling, C.B., were these: fasting, $52 \mathrm{mg}$ per $100 \mathrm{ml} ; 3$ hours, $152 \mathrm{mg}$ per $100 \mathrm{ml}$;

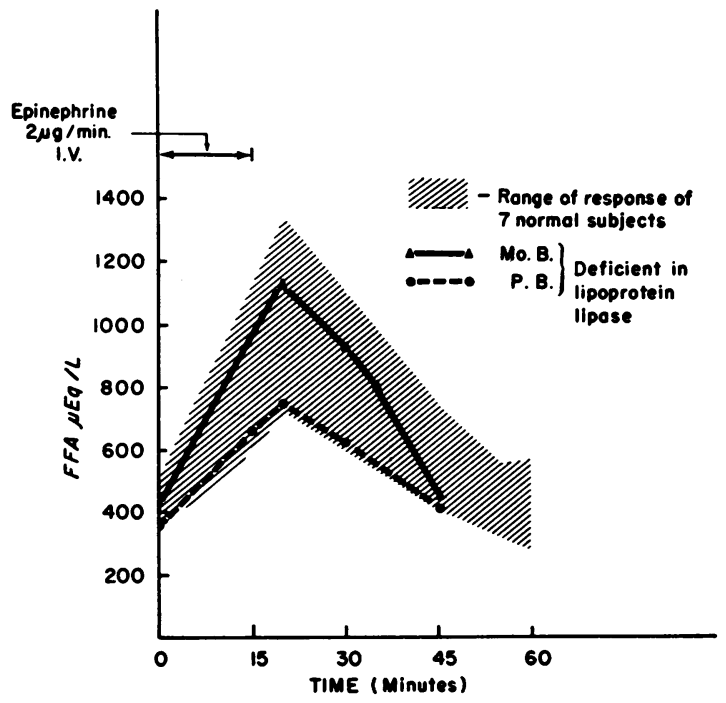

Fig. 3. AsSESSMENT OF THE HORMONE-SENSITIVE LIPOLYTIC SYSTEM IN THE TWO HYPERLIPEMIC SUBJECTS. After a standard epinephrine infusion, the rise in free fatty acids (FFA) was within the range of normal response as indicated by the shaded area.
5 hours, $182 \mathrm{mg}$ per $100 \mathrm{ml}$; and 8 hours, $114 \mathrm{mg}$ per $100 \mathrm{ml}$. This response was similar to that in normal individuals.

Assessment of the hormone-sensitive lipolytic system by epinephrine infusion. Basal levels of plasma FFA were normal in the two homozygotic subjects. Mobilization of FFA after infusion of epinephrine was normal when compared with the response in normal subjects (Figure 3). As noted previously, this quantity of epinephrine is the least amount eliciting a consistent rise in FFA and is, therefore, a sensitive test of this lipolytic system (17).

\section{Discussion}

Since the amount and composition of plasma triglyceride in exogenous hypertriglyceridemia are dependent on dietary composition, it was suggested that this disorder is related to an abnormality in the assimilation of alimentary triglyceride into tissues. Although other mechanisms for removal of plasma triglyceride have been described $(25,26)$, the most important physiological mechanism is presumed to be hydrolysis of lipoprotein triglyceride to fatty acid and cellular uptake of these fatty acids. The enzyme, lipoprotein lipase, facilitates hydrolysis of the triglyceride moiety of lipoproteins and is the only known lipolytic enzyme with a substrate preference for lipoproteins. This enzyme is present in many tissues, except possibly the liver, but its physiologic importance in the deposition of alimentary fat has been questioned (27). Patients with exogenous hyperglyceridemia were found to have a deficiency of lipase activity in postheparin plasma, and this decreased plasma activity was assumed to reflect a deficiency of tissue enzyme $(2,5)$. The observations that there was no intrinsic abnormality of lipoproteins and that removal of lipemic blood from normal subjects was delayed in these patients further supported the concept that removal from plasma was abnormal (2).

The present studies demonstrate the presence of lipoprotein lipase in adipose tissue of normal human subjects and a marked deficiency of LLA in individuals with exogenous ("fat-induced") hyperlipemia. The lipase activity assayed in these studies had the characteristic features of lipoprotein lipase $(3,4)$. Enzymatic activity was increased by feeding and inhibited by sodium chloride or protamine sulfate, and there was no hy- 
drolysis of triglyceride in the absence of serum. These characteristics and optimal activity at alkaline $\mathrm{pH}$ differentiate lipoprotein lipase from lipolytic enzymes that mobilize FFA from adipose tissue in response to starvation and various hormones, including catecholamines. This latter lipolytic system was assessed by measuring the increase of FFA after epinephrine infusion and was found to be normal in the hyperlipemic subjects that had deficient LLA.

With a sensitive and reliable assay, exact classification of members of the affected kindred was possible, and this permitted determination of the genetics of this disorder. The propositus and two siblings had postabsorptive hypertriglyceridemia and chylomicronemia ; the two siblings had marked LLA deficiencies. Both parents and one sibling had levels of LLA intermediate between normal and those of the hyperlipemic offspring. One sibling was apparently normal, although she would not permit an assay of tissue LLA (Figure 1). These observations are compatible with an autosomal recessive inheritance, two abnormal alleles conveying grossly deficient levels of tissue LLA and postabsorptive chylomicronemia. Parental consanguinity in this family and the apparent rarity of this disorder in the general population are also compatible with recessive inheritance (5). Individuals heterozygotic for this trait have normal postabsorptive triglyceride levels, but abnormal removal of a fat meal. In addition, these individuals, like some presumed heterozygotes from other kindred (2), have serum cholesterol levels significantly higher than normal family members, and this finding is associated with elevation of beta lipoproteins. The reason for this elevation is unclear since lipoprotein lipase is not thought to be important in removal of the beta lipoprotein fractions. However, beta lipoproteins are components of the prebeta or very low density lipoproteins, which are probably removed by lipoprotein lipase, and impaired handling of this fraction may be related to elevation of beta lipoproteins.

The physiologic importance of lipoprotein lipase is demonstrated by comparison of alimentary triglyceride removal in normal subjects and in those with deficient LLA. In normal subjects, ingestion of a moderate fat meal was followed by an increase in triglyceride that was present initially ( 3 to 5 hours) in the chylomicron and trail frac- tions and later ( 5 to 8 hours) in the prebeta and trail lipoproteins. Other studies $(24,28)$ have demonstrated that alimentary triglyceride, found initially in the particulate fat (chylomicrons), appears later in the very low density lipoproteins. The mechanism of this transformation of alimentary triglyceride is not clear, but it has been suggested that chylomicrons are removed by the liver or other tissues and some of this triglyceride is secreted as very low density lipoproteins (27). Heterozygotic subjects with intermediate levels of LLA had a greater rise in plasma triglyceride and in particulate fat and very low density lipoproteins after the fat meal. Since the pool size of these lipids preceding the meal was normal, this suggests that removal of these lipid fractions was impaired. Although these data are consistent, the limited number of observations and the variable response noted with fat tolerance tests recommend some caution in their interpretation. Delayed removal of lipemic blood infused intravenously has also been demonstrated (2). There is other indirect evidence that lipoprotein lipase participates in removal of triglyceride from very low density lipoproteins as well as from chylomicrons. Havel, Felts, and Van Duyne (29) found removal of triglyceride from these lipoproteins and deposition in adipose tissue to be markedly increased by feeding, which stimulates lipoprotein lipase activity. Similarly, tissue incorporation of triglyceride from these lipoproteins was found to be related to lipoprotein lipase activity in the tissue (23). The importance of lipoprotein lipase in clearing chylomicrons is demonstrated by the increasing chylomicronemia in the homozygotic subject after the fat meal. There was no increase in very low density lipoproteins in this subject, and this suggests that lipoprotein lipase may be related to the formation of these lipoproteins from chylomicrons. However, these studies are too limited to delineate this point or to clarify the role of the liver in this change. The importance of lipoprotein lipase in removal of both particulate fat and very low density lipoproteins is clear from these observations, and adipose tissue is an important site of action of this enzyme.

Other aspects of the relationship between lipoprotein lipase and hypertriglyceridemia are clarified by these studies. Despite reduced LLA and delayed removal of alimentary triglyceride in 
heterozygotic individuals, postabsorptive levels of triglyceride and very low density lipoproteins were normal. Therefore, moderate deficiencies of lipoprotein lipase per se are not responsible for postprandial triglyceride elevation if endogenous production is normal. Normal levels of tissue LLA in P.W., a healthy subject with endogenous hypertriglyceridemia, also support the thesis that triglyceride removal is normal in individuals with endogenous hypertriglyceridemia. However, other aspects of triglyceride assimilation, including re-esterification of the hydrolyzed fatty acids by the tissue, were not evaluated (20). Studies of turnover rates of triglyceride in endogenous hypertriglyceridemia are consistent with the concept that overproduction exceeds the capacity of the removal mechanism (30). A relatively fixed rate of clearance, although normal, could further increase plasma triglyceride by failing to increase in response to the triglyceride load. The consistent levels of LLA, lower in humans than animals, suggest that lipoprotein lipase has a limited capacity to adapt to increased triglyceride levels as typified by subject P.W.

\section{Acknowledgments}

We are indebted to Mrs. Barbara Hale and Miss Christine Spiers for their technical assistance and to the Department of Biostatistics for analysis of data. Dr. Myron Kauffman, Department of Surgery, obtained the adipose tissue samples for assay.

\section{References}

1. Ahrens, E. H., Jr., J. Hirsch, K. Oette, J. W. Farquhar, and Y. Stein. Carbohydrate-induced and fatinduced lipemia. Trans. Ass. Amer. Phycns 1961, 74, 134.

2. Havel, R. J., and R. S. Gordon, Jr. Idiopathic hyperlipemia: metabolic studies in an affected family. J. clin. Invest. 1960, 39, 1777.

3. Korn, E. D. Clearing factor, a heparin-activated lipoprotein lipase. I. Isolation and characterization of the enzyme from normal rat heart. J. biol. Chem. 1955, 215, 1.

4. Korn, E. D., and T. W. Quigley, Jr. Studies on lipoprotein lipase of rat heart and adipose tissue. Biochim. biophys. Acta (Amst.) 1955, 18, 143.

5. Fredrickson, D. S., K. Ono, and L. L. Davis. Lipolytic activity of post-heparin plasma in hyperglyceridemia. J. Lipid Res. 1963, 4, 24.

6. Furman, R. H., R. P. Howard, O. J. Brusco, and P. Alaupovic. Effects of medium chain length triglyceride (MCT) on serum lipids and lipoproteins in familial hyperchylomicronemia (dietary fat-induced lipemia) and dietary carbohydrateaccentuated lipemia. J. Lab. clin. Med. 1965, 66, 912.

7. Hudson, P., and J. H. Moon. Clinicopathological conference. Virginia med. Mth. 1965, 92, 321.

8. Forbes, J. C., P. D. Camp, A. J. Wasserman, W. T. Tucker, A. L. Forbes, and O. M. Petterson. Effect of centrifugation at $20,000 \times g$ on lipid distribution of human sera. Proc. Soc. exp. Biol. (N. Y.) 1961, 107, 224.

9. Robinson, D. S. Changes in the lipolytic activity of the guinea pig mammary gland at parturition. J. Lipid Res. 1963, 4, 21.

10. Dole, V. P. A relation between non-esterified fatty acids in plasma and the metabolism of glucose. J. clin. Invest. 1956, 35, 150.

11. Salaman, M. R., and D. S. Robinson. The effect of fasting on the clearing factor lipase activity of rat adipose tissue and plasma in The Biochemical Problems of Lipids (6th International Conference), $\mathrm{P}$. Desnuelle, Ed. New York, Pergamon, 1961, p. 218.

12. Van Handel, E., and D. B. Zilversmit. Micromethod for the direct determination of serum triglycerides. J. Lab. clin. Med. 1957, 50, 152.

13. Abell, L. L., B. B. Levy, B. B. Brodie, and F. E. Kendall. A simplified method for the estimation of total cholesterol in serum and demonstration of its specificity. J. biol. Chem. 1952, 195, 357.

14. Marinetti, G. V., M. Albrecht, T. Ford, and E. Stotz. Analysis of human plasma phosphatides by paper chromatography. Biochim. biophys. Acta (Amst.) 1959, 36, 4.

15. Lees, R. S., and F. T. Hatch. Sharper separation of lipoprotein species by paper electrophoresis in albumin-containing buffer. J. Lab. clin. Med. 1963, $61,518$.

16. De Lalla, O. F., and J. W. Gofman. Ultracentrifugal analysis of serum lipoproteins in Methods of Biochemical Analysis, D. Glick, Ed. New York, Interscience, 1954, vol. 1, p. 459.

17. Harlan, W. R., J. Laszlo, M. D. Bogdonoff, and E. H. Estes, Jr. Alterations in free fatty acid metabolism in endocrine disorders. I. Effect of thyroid hormone. J. clin. Endocr. 1963, 23, 33.

18. Harlan, W. R., Jr., P. S. Winesett, and A. J. Wasserman. Unpublished observations.

19. Lees, R. S., and D. S. Fredrickson. The differentiation of exogenous and endogenous hyperlipemia by paper electrophoresis. J. clin. Invest. 1965, 44, 1968.

20. Knittle, J. L., and E. H. Ahrens, Jr. Carbohydrate metabolism in two forms of hyperglyceridemia. J. clin. Invest. 1964, 43, 485.

21. Stern, C. A., J. M. Iacono, and J. F. Mueller. Lipoprotein lipase in human adipose tissue. Proc. Soc. exp. Biol. (N. Y.) 1962, 110, 366.

22. Nestel, P. J., and R. J. Havel. Lipoprotein lipase in human adipose tissue. Proc. Soc. exp. Biol. (N. Y.) 1962, 109, 985.

23. Bezman, A., J. M. Felts, and R. J. Havel. Relation between incorporation of triglyceride fatty acids 
and heparin-released lipoprotein lipase from adipose tissue slices. J. Lipid Res. 1962, 3, 427.

24. Harlan, W. R., Jr., and D. E. Beischer. Changes in serum lipoproteins after a large fat meal in normal individuals and in patients with ischemic heart disease. Amer. Heart J. 1963, 66, 61.

25. Di Luzio, N. R. Reticuloendothelial involvement in lipid metabolism. Ann. N. Y. Acad. Sci. 1960, 88, 244.

26. Ashworth, C. T., V. A. Stembridge, and E. Sanders. Lipid absorption, transport and hepatic assimilation studied with electron microscopy. Amer. J. Physiol. 1960, 198, 1326.
27. Dole, V. P., and J. T. Hamlin III. Particulate fat in lymph and blood. Physiol. Rev. 1962, 42, 674.

28. Havel, R. J. Early effects of fat ingestion on lipids and lipoproteins of serum in man. J. clin. Invest. 1957, 36, 848.

29. Havel, R. J., J. M. Felts, and C. M. Van Duyne. Formation and fate of endogenous triglycerides in blood plasma of rabbits. J. Lipid Res. 1962, 3, 297.

30. Reaven, G. M., D. B. Hill, R. C. Gross, and J. W. Farquhar. Kinetics of triglyceride turnover of very low density lipoproteins of human plasma. J. clin. Invest. 1965, 44, 1826. 